\title{
Effects of eucalypt residue management on nutrient leaching and soil properties
}

\author{
M. X. Gómez-Rey • E. Vasconcelos • M. Madeira
}

Received: 30 January 2006 / Revised: 15 November 2006 / Accepted: 22 February 2008 / Published online: 14 May 2008

(c) Springer-Verlag 2008

\begin{abstract}
Effects of harvest residues on nutrient leaching and soil chemical properties were studied in a lysimeter experiment. Treatments were: (A) forest floor litter and harvest residues, other than branches, incorporated into the soil, (B) as A, but with branches cut in $20 \mathrm{~cm}$ long bits and placed on the soil surface, (C) as B, but with bits incorporated into the soil, (D) as B, but with branches chopped into chips, (E) as C, but with branches chopped into chips, (F) forest floor litter and harvest residues on the soil surface, with branches cut in $20 \mathrm{~cm}$ long bits, (G) as F, but with branches chopped into chips, and $(\mathrm{H})$ absence of harvest residues (control). Treatments were applied in zero-tension lysimeters containing $25 \mathrm{~kg}$ of soil. Leachates were collected for a 6-year period. At the end of the experiment, lysimeters were dismantled and soil was divided in four layers. Residues, other than branches, increased $\mathrm{N}$ leaching, as compared with the control. Branches on the soil surface reduced $\mathrm{N}$ leaching when cut in chips. Branches incorporated into the soil reduced leaching independently of their size. Organic residues on the soil surface showed similar effect to those incorporated into the soil. However, harvest residues on the soil surface increased leachate volume, and reduced $\mathrm{Ca}$ and $\mathrm{P}$ losses. Such a placement of residues led to high contents of $\mathrm{Ca}$ and $\mathrm{P}$ in the $0-5 \mathrm{~cm}$ top soil layer.
\end{abstract}

Communicated by F. Makeschin.

M. X. Gómez-Rey $(\bowtie) \cdot$ M. Madeira

Departamento de Ciências do Ambiente,

Instituto Superior de Agronomia, Tapada de Ajuda,

1349-017 Lisbon, Portugal

e-mail: mxgomez@isa.utl.pt

E. Vasconcelos

Departamento de Química Agrícola e Ambiental,

Instituto Superior de Agronomia, Tapada de Ajuda,

1349-017 Lisbon, Portugal
Contents of organic $\mathrm{C}$, total $\mathrm{N}$ and base cations were not affected by the treatments.

Keywords Harvest residues - Eucalyptus globulus . Nutrient leaching · Residue quality · Residue management . Soil nutrients

\section{Introduction}

Eucalypt plantations in Portugal, intensively managed as coppice stands, occupy about $20 \%$ of the forested area and are mostly grown on soils low in organic matter and nutrients. At the end of their rotation period, the amounts of $\mathrm{N}$ and $\mathrm{Ca}$ in harvest residues and forest floor reach 630 and $1,080 \mathrm{~kg} \mathrm{ha}^{-1}$, respectively (Madeira 1989, 1995). The amounts of $\mathrm{Ca}$ and $\mathrm{P}$ in these residues are frequently of the same magnitude as of those measured in the top soil. As harvest residues are frequently removed from the site for energy purposes and for post-harvest operational reasons, soil fertility in following rotations may decline due to losses of organic matter and nutrients. Management of harvest residues is one way of manipulating site fertility in short-rotation plantations, given that harvest residues generally contain substantial stocks of nutrients (Smethurst and Nambiar 1990). Additionally, woody residues with high $\mathrm{C} / \mathrm{N}$ ratios should have the potential to immobilise $\mathrm{N}$ and to reduce leaching and availability of $\mathrm{N}$ (Vitousek and Matson 1985). Within this context a field trial was installed in Portugal in 1993 to test whether site productivity and fertility is affected by harvest residue management (Jones et al. 1999). Results showed that tree nutrition status and productivity and soil properties (nitrogen availability and soil organic carbon content) were not affected by removal of residues and by residue placement (Madeira et al. 2004). This does 
not agree with the decline in tree productivity after the first rotation which has been noted in various parts of the world (Haywood 1994; Proe and Dutch 1994), for several forest species, where harvest residues were removed.

To evaluate the specific effect of organic residue management on soil fertility and chemical properties, an experiment was carried out under controlled conditions (a lysimetric system), in the absence of plants. In this experiment, field treatments were simulated and the effects of woody residue fragmentation degree (bits or chips) and placement (soil surface or incorporated) were taken into account. Effects of organic residue management on nutrient leaching, soil chemical properties and accumulation of organic carbon in mineral soil are examined in this study.

\section{Materials and methods}

\section{Lysimeter and treatments}

The lysimeter experiment was located at Instituto Superior de Agronomia, Lisboa. The area has a Mediterranean climate, tempered by an oceanic influence. The annual mean temperature is $16.4^{\circ} \mathrm{C}$, and the annual mean precipitation is $730 \mathrm{~mm}$, of that approximately $75 \%$ from November to April (INMG 1991). Temperature and rainfall were monitored daily during the study period (1997-2003). Annual mean temperature was $16.8^{\circ} \mathrm{C}$, ranging from a monthly mean of $9.6^{\circ} \mathrm{C}$ in January to $23.4^{\circ} \mathrm{C}$ in August. The annual mean rainfall was $780 \mathrm{~mm}$, and two periods had high rainfall amounts (from October to December 1997 and from November 2000 to March 2001).

The lysimeter station consisted of 40 lysimeters constructed in PVC, with a surface area of $0.068 \mathrm{~m}^{2}$, an inner diameter of $29.5 \mathrm{~cm}$ and a depth of $50 \mathrm{~cm}$. At the bottom they had a drainage zone with double plastic mesh $(2 \mathrm{~mm})$, gravel layer (2-5 and 5-10 $\mathrm{mm}$ diameter), double layer of filtering material and sand layer. At the base, the leachates were collected continuously with a flask, and were kept in the dark to avoid growth of algae in the sample. Lysimeters were exposed to natural weather conditions in an open area. They were placed $1 \mathrm{~m}$ apart on a concrete base with openings for the drainage tubes, the surrounding space between them having been filled with sand material covered by pine bark. Lysimeter top edges were $10 \mathrm{~cm}$ above covering bark surface.

Eight treatments involving different residue management are described in Table 1. Treatments were installed in a randomized block design, being replicated five times.

Sieved homogenised soil ( $25 \mathrm{~kg}$, dry weight) was introduced in each lysimeter. According to the treatment, this mineral substrate was mixed with $500 \mathrm{~g}$ (dry weight) of forest floor litter (equivalent to $70 \mathrm{tha}^{-1}$ ) and with $1,488 \mathrm{~g}$ of harvest residues: $300 \mathrm{~g}$ of leaves, $88 \mathrm{~g}$ of bark, $100 \mathrm{~g}$ of twigs and $1,000 \mathrm{~g}$ of branches $(42.0,12.3,14.0$ and $140.0 \mathrm{tha}^{-1}$, respectively), packed at a bulk density of $1.3 \mathrm{~g} \mathrm{~cm}^{-3}$. These amounts were two to three times greater than those measured at the end of the first rotation of eucalypt plantations in Portugal (Jones et al. 1999), in order to stress differences between treatments.

The experiment was carried out from April 1997 to April 2003. Given the scarce rainfall, in order to obtain enough leachates, distilled water $(5-15 \mathrm{~mm})$ was weekly added to the lysimeters in April, May and September 1997. In these months, one of the weekly supplies of distilled water contained $0.27 \mathrm{~g} \mathrm{~N} \mathrm{~L}^{-1} \quad\left(\left(\mathrm{NH}_{4}\right)_{2} \mathrm{SO}_{4}\right)$ and $1.36 \mathrm{~g} \mathrm{P} \mathrm{L}^{-1}$ $\left(\mathrm{NaH}_{2} \mathrm{PO}_{4}\right)$. Fertilizers were applied since a treatment with grass was initially considered, but had to be dropped because of damage by birds and rabbits. Weed growth in lysimeters was controlled during the experiment period by hand.

\section{Materials}

The lysimeters were filled with mineral substrate (Ah horizon) and organic residues (forest floor litter and harvest residues) collected at the end of the rotation period (March

Table 1 Description of treatments and amount (g) of nutrient elements added in each lysimeter as forest floor litter and harvest residues

\begin{tabular}{|c|c|c|c|c|c|c|c|c|c|c|}
\hline \multirow[t]{2}{*}{ Treat. } & \multirow{2}{*}{$\begin{array}{l}\text { Forest floor } \\
\text { placement }\end{array}$} & \multirow[t]{2}{*}{ LBT } & \multicolumn{2}{|l|}{ Branches } & \multicolumn{6}{|c|}{ Amount added per lysimeter } \\
\hline & & & Fragmentation & Placement & $\mathrm{OM}$ & $\mathrm{N}$ & $\mathrm{P}$ & $\mathrm{K}$ & $\mathrm{Ca}$ & $\mathrm{Mg}$ \\
\hline A & Incorporated & Incorporated & - & - & 988 & 7.42 & 0.79 & 3.06 & 8.83 & 1.60 \\
\hline B & Incorporated & Incorporated & Bits $(20 \mathrm{~cm})$ & Surface & 1,988 & 8.61 & 0.81 & 3.35 & 13.96 & 2.05 \\
\hline $\mathrm{C}$ & Incorporated & Incorporated & Bits $(20 \mathrm{~cm})$ & Incorporated & 1,988 & 8.61 & 0.81 & 3.35 & 13.96 & 2.05 \\
\hline $\mathrm{D}$ & Incorporated & Incorporated & Chips & Surface & 1,988 & 8.61 & 0.81 & 3.35 & 13.96 & 2.05 \\
\hline $\mathrm{E}$ & Incorporated & Incorporated & Chips & Incorporated & 1,988 & 8.61 & 0.81 & 3.35 & 13.96 & 2.05 \\
\hline $\mathrm{F}$ & Surface & Surface & Bits $(20 \mathrm{~cm})$ & Surface & 1,988 & 8.61 & 0.81 & 3.35 & 13.96 & 2.05 \\
\hline G & Surface & Surface & Chips & Surface & 1,988 & 8.61 & 0.81 & 3.35 & 13.96 & 2.05 \\
\hline $\mathrm{H}$ & - & - & - & - & 0 & 0 & 0 & 0 & 0 & 0 \\
\hline
\end{tabular}

LBT Leaves, bark and twigs, $O M$ organic matter 
1997), from a 12-year-old Eucalyptus globulus plantation located $70 \mathrm{~km}$ east of Lisboa. The soil was a Dystric Cambisol (WRB 2006) developed on miocenic sandstones.

The mineral substrate was sieved $(<5 \mathrm{~mm})$ and subsequently five subsamples were taken for analysis. The mineral substrate was sandy to loamy sand with $\mathrm{pH} 4.9$, being other characteristics shown in the Table 2.

The harvest residues (leaves, bark, twigs with diameter $<5 \mathrm{~mm}$ and branches corresponding to the fraction 20$30 \mathrm{~mm})$ were sampled and dried $\left(45^{\circ} \mathrm{C}\right)$. Twigs and branches were cut into $12-$ and $20-\mathrm{cm}$ long pieces, respectively. Half of the branch pieces were chopped into chips, resulting in an increase of their surface by approximately 90 times. The bark was also divided into sections with an area of about $12 \mathrm{~cm}^{2}$. Nutrient contents of forest floor litter and of harvest residue components were determined from three subsamples of bulked material (Table 3 ).

\section{Sampling}

Volume of leachates was recorded, and was bulked for analysis in proportion to the rain during the period. At the end of the experiment (May 2003), the lysimeters were dismantled to find changes of soil properties. Soil was divided into 0-5, 5-10, 10-20 and 20-30 cm layers to assess depthwise changes. The organic residues both remaining on the soil surface and incorporated into the soil were collected separately and dried $\left(45^{\circ} \mathrm{C}\right)$ for chemical analysis.

\section{Laboratory procedures}

Leachates were filtered $(0.45 \mu \mathrm{m})$ and stored at $-15^{\circ} \mathrm{C}$ until analysis. Concentrations of $\mathrm{N}-\mathrm{NO}_{3}{ }^{-}$and $\mathrm{N}-\mathrm{NH}_{4}{ }^{+}$ were determined by a segmented flow autoanalyzer, using the hydrazinium reduction and the modified Berthelot method, respectively.

Organic residues were ground in a laboratory mill to a particle size $<1 \mathrm{~mm}$ for chemical analysis. Ash-free dry weight was determined by dry combustion for $6 \mathrm{~h}$ at $450^{\circ} \mathrm{C}$. The mineral elements ( $\mathrm{Ca}, \mathrm{Mg}, \mathrm{K}$ and $\mathrm{P}$ ) were determined after ashing which was taken up in $\mathrm{HCl}$. Total $\mathrm{N}$ was determined using Kjeldhal digestion. The carbon amount was calculated assuming an average carbon content of $50 \%$ of ash-free mass.

Soil properties were determined on the fine earth fraction ( $<2 \mathrm{~mm}$ ), following the methodology described by Póvoas and Barral (1992). Soil pH was determined potentiometrically in water and $1 \mathrm{M} \mathrm{KCl}$. The non-humified organic matter fraction was separated by a $50 \mu \mathrm{m}$ sieve, following the methodology described by Bruckert (1979). The organic C in both the bulk samples and the non-humified organic matter fraction was determined by wet oxidation. Total $\mathrm{N}$ was determined as above. Extractable $\mathrm{P}$ and $\mathrm{K}$ were extracted using the Egner-Riehm method. The exchangeable base cations were extracted by $1 \mathrm{M} \mathrm{NH}_{4} \mathrm{OAc}$, adjusted at $\mathrm{pH}$ 7.0, and the extractable $\mathrm{Al}$ was determined after extraction with $1 \mathrm{M} \mathrm{KCl}$. The $\mathrm{Ca}, \mathrm{Mg}, \mathrm{Na}, \mathrm{K}$ and $\mathrm{Al}$ of the extracts and solutions were quantified by atomic absorption spectroscopy and $\mathrm{P}$ was determined by the molybdate-blue method.

\section{Statistical analysis}

The treatments were compared in terms of nutrient leaching and soil properties by analysis of variance (ANOVA) using Statistica 5.0 software package (StatSoft 1996). Differences between treatments were tested using the Tukey multiple range test.

Table 2 Particle size (SA, sand; ST, silt; CL, clay), pH values and contents of organic C, N, exchangeable bases, extractable Al and extractable $\mathrm{P}$ and $\mathrm{K}$ of the mineral substrate $\left(<2 \mathrm{~mm}, 105^{\circ} \mathrm{C}\right.$ dry weight $)$ used in the lysimeters

\begin{tabular}{|c|c|c|c|c|c|c|c|c|c|c|c|c|c|c|}
\hline \multicolumn{6}{|c|}{ Particle size $\left(\mathrm{g} \mathrm{kg}^{-1}\right)$} & \multicolumn{2}{|l|}{$\mathrm{pH}$} & \multicolumn{4}{|c|}{ Exchangeable $\left(\mathrm{cmol}_{\mathrm{c}} \mathrm{kg}^{-1}\right)$} & \multirow[b]{2}{*}{$\mathrm{Al}^{3+}$} & \multicolumn{2}{|c|}{$\begin{array}{l}\text { Extractable } \\
\left(\mathrm{mg} \mathrm{kg}^{-1}\right)\end{array}$} \\
\hline SA & $\mathrm{ST}$ & $\mathrm{CL}$ & $\mathrm{C}$ & $\mathrm{N}$ & $\mathrm{C} / \mathrm{N}$ & $\mathrm{H}_{2} \mathrm{O}$ & $\mathrm{KCl}$ & $\overline{\mathrm{Ca}^{2+}}$ & $\mathrm{Mg}^{2+}$ & $\mathrm{Na}^{+}$ & $\mathrm{K}^{+}$ & & $\bar{P}$ & $\mathrm{~K}$ \\
\hline $\begin{array}{l}907 \\
(14)\end{array}$ & $\begin{array}{l}73 \\
\text { (4) }\end{array}$ & $\begin{array}{l}20 \\
\text { (3) }\end{array}$ & $\begin{array}{l}11.9 \\
(0.67)\end{array}$ & $\begin{array}{l}0.52 \\
\quad(0.00)\end{array}$ & $\begin{array}{l}22.8 \\
(1.2)\end{array}$ & $\begin{array}{l}4.90 \\
\quad(0.81)\end{array}$ & $\begin{array}{l}3.85 \\
\quad(0.46)\end{array}$ & $\begin{array}{l}0.44 \\
\quad(0.03)\end{array}$ & $\begin{array}{l}0.15 \\
\quad(0.01)\end{array}$ & $\begin{array}{l}0.11 \\
\quad(0.01)\end{array}$ & $\begin{array}{l}0.06 \\
(0.00)\end{array}$ & $\begin{array}{l}0.56 \\
\quad(0.03)\end{array}$ & $\begin{array}{l}2.0 \\
(0.6)\end{array}$ & $\begin{array}{l}23.9 \\
\quad(0.6)\end{array}$ \\
\hline
\end{tabular}

Values are means $(n=5)$ and standard deviation $(\mathrm{SD})$ between brackets

Table 3 Nutrient contents ( $\mathrm{mg} \mathrm{g}^{-1}$ ash-free dry mass) from forest floor litter (FFL) and harvest residues ( $L V$ leaves, $B K$ bark, $T W$ twigs, $B R$ branches) used in the lysimeters

Values are means $(n=3) \pm \mathrm{SD}$

\begin{tabular}{llllll}
\hline Nutrient & FFL & LV & BK & TW & BR \\
\hline $\mathrm{N}$ & $6.71 \pm 0.05$ & $12.06 \pm 0.11$ & $1.29 \pm 0.10$ & $3.38 \pm 0.40$ & $1.19 \pm 0.17$ \\
$\mathrm{P}$ & $0.32 \pm 0.02$ & $0.92 \pm 0.04$ & $0.18 \pm 0.01$ & $0.38 \pm 0.20$ & $0.12 \pm 0.02$ \\
$\mathrm{~K}$ & $0.57 \pm 0.06$ & $5.43 \pm 0.15$ & $2.27 \pm 0.06$ & $2.87 \pm 0.76$ & $0.97 \pm 0.06$ \\
$\mathrm{Ca}$ & $7.77 \pm 0.06$ & $7.73 \pm 0.21$ & $15.10 \pm 0.17$ & $12.93 \pm 3.95$ & $5.13 \pm 0.84$ \\
$\mathrm{Mg}$ & $0.90 \pm 0.00$ & $1.63 \pm 0.06$ & $1.90 \pm 0.00$ & $1.40 \pm 0.26$ & $0.80 \pm 0.00$ \\
$\mathrm{C} / \mathrm{N}$ & 75 & 41 & 388 & 148 & 420 \\
$\mathrm{C} / \mathrm{P}$ & 1,563 & 543 & 2,776 & 1,315 & 4,167 \\
\hline
\end{tabular}




\section{Results}

Leachate amounts

The cumulative amount of leachates collected during the experimental period was smaller than that of rainfall $(4,883 \mathrm{~mm})$ and varied among treatments (Table 4$)$. At the end of the experiment, the accumulated volume was greater $(3,456-4,035 \mathrm{~mm})$ in treatments where the surface of the mineral substrate was covered by organic residues (treatments B, D, F and G). The volume in treatments D and F was significantly greater than in the others. The smallest amount of leachate was measured in the control $(3,034 \mathrm{~mm})$, where organic residues were absent. Such volume was not significantly different from that measured in treatments A, C and E (3,119-3,245 mm) where residues were incorporated into the soil.

\section{Nutrient leaching}

Mineral $\mathrm{N}$ in leachates of the control $(\mathrm{H})$ amounted to $1.09 \mathrm{~g}$ (Table 4). Its amount in lysimeters with organic residues incorporated into the soil, in the absence of branches (treatment A) was 1.5 greater, but the difference between the two was not significant. The presence of branches, cut in $20 \mathrm{~cm}$ long bits and placed on the soil surface (treatment $\mathrm{B})$, reduced $\mathrm{N}$ leaching (1.28 g) and was similar to that measured in the control. Incorporation of branch bits (treatment C) strongly decreased the amount of $\mathrm{N}$ leached $(0.47 \mathrm{~g})$, which was significantly lower than that measured in $\mathrm{H}, \mathrm{A}$ and $\mathrm{B}$ treatments. Branches chopped into chips, placed on the soil surface (treatment D) or incorporated into the soil (treatment E), showed losses of $\mathrm{N}$ (respectively, 0.77 and $0.74 \mathrm{~g}$ ) which were not significantly different from those measured in the $\mathrm{B}$ and $\mathrm{C}$ treatments. The amounts in treatments with residues on the soil surface, either branches in $20 \mathrm{~cm}$ long bits (treatment F) or in chips (treatment $\mathrm{G}$ ), respectively 0.97 and $0.74 \mathrm{~g}$, were not significantly different from the other treatments. In treatments $\mathrm{F}$ and $\mathrm{G}, \mathrm{N}$ leached as $\mathrm{NH}_{4}^{+}$was about one-third of the total.

Amounts of $\mathrm{Ca}, \mathrm{Mg}$ and $\mathrm{K}$ in leachates were generally greater in the treatments with residues than in the control (Table 4). Leaching of $\mathrm{Ca}$ was highest in treatment $\mathrm{E}$ (5.04 g), being significantly higher than in C, F, G and $\mathrm{H}$. Treatments with the organic residues on the soil surface (treatments F and G) showed the lowest Ca losses (2.86$3.04 \mathrm{~g}$ ), which were of the same magnitude as those observed in the control (3.16 g). The amounts of Mg measured in leachates of the control $(0.77 \mathrm{~g})$ were smaller than in the others (0.97-1.41 g), but differences were only significant relatively to treatments $\mathrm{D}$ and $\mathrm{E}$. Losses of $\mathrm{K}$ in all treatments (2.20-3.57 g) were also statistically higher than in the control $(0.71 \mathrm{~g})$. The highest values of $\mathrm{Ca}, \mathrm{Mg}$ and $\mathrm{K}$ were found in the E treatment.

Leaching of $\mathrm{P}$ was small as compared with $\mathrm{Ca}, \mathrm{Mg}$ and $\mathrm{K}$, and did not show significant differences among treatments. As observed for the base cations, the amount of $\mathrm{P}$ leached was lower $(6.9 \mathrm{mg})$ in the control than in the others (11.7-23.5 mg). Moreover, as it was observed for $\mathrm{Ca}$, the amounts of $\mathrm{P}$ in the leachates of the treatments $\mathrm{F}$ and $\mathrm{G}$ (with the organic residues on the soil surface) were smaller than in A, B, C, D and E.

\section{Soil properties}

At the end of experiment, values of $\mathrm{pH}-\mathrm{H}_{2} \mathrm{O}$ and $\mathrm{pH}-\mathrm{KCl}$ in soil surface $(0-10 \mathrm{~cm})$ were similar among treatments but for all depths the values were statistically higher $(P<0.05)$ than those observed in the control (Fig. 1). These values were also higher than those measured in the mineral substrate at the beginning of the experiment (as shown in Table 1 and by the arrows in Fig. 1).

The amounts of branch residues (treatments B and D) and harvest residues (treatments $\mathrm{F}$ and $\mathrm{G}$ ) remaining on the

Table 4 Accumulated volume and nutrients in the leachates collected in lysimeters of different treatments during the experimental period (April 1997-April 2003)

\begin{tabular}{lllllllll}
\hline Treat. & Volume $(\mathrm{mm})$ & $\begin{array}{l}\mathrm{NO}_{3}-\mathrm{N} \\
\left(\mathrm{g} \mathrm{lysimeter}^{-1}\right)\end{array}$ & $\begin{array}{l}\mathrm{NH}_{4}-\mathrm{N} \\
\left(\mathrm{g} \mathrm{lysimeter}^{-1}\right)\end{array}$ & $\begin{array}{l}\left(\mathrm{NO}_{3}+\mathrm{NH}_{4}\right)-\mathrm{N} \\
\left(\mathrm{g} \mathrm{lysimeter}^{-1}\right)\end{array}$ & $\begin{array}{l}\mathrm{Ca} \\
\left(\mathrm{g} l y s i m e t e r^{-1}\right)\end{array}$ & $\begin{array}{l}\mathrm{Mg} \\
\left(\mathrm{g} \mathrm{lysimeter}^{-1}\right)\end{array}$ & $\begin{array}{l}\mathrm{K} \\
\left(\mathrm{g} \mathrm{lysimeter}^{-1}\right)\end{array}$ & $\begin{array}{l}\mathrm{P} \\
\left(\mathrm{mg} \mathrm{lysimeter}^{-1}\right)\end{array}$ \\
\hline $\mathrm{A}$ & $3,219.1^{\mathrm{ad}}(128.1)$ & $1.41^{\mathrm{a}}(0.25)$ & $0.16^{\mathrm{ac}}(0.02)$ & $1.57^{\mathrm{a}}(0.23)$ & $4.32^{\mathrm{bc}}(0.40)$ & $1.04^{\mathrm{bc}}(0.09)$ & $2.59^{\mathrm{ab}}(0.46)$ & $23.5^{\mathrm{a}}(9.8)$ \\
$\mathrm{B}$ & $3,511.5^{\mathrm{b}}(84.1)$ & $1.11^{\mathrm{ac}}(0.43)$ & $0.17^{\mathrm{ac}}(0.02)$ & $1.28^{\mathrm{ac}}(0.44)$ & $4.27^{\mathrm{bc}}(0.67)$ & $1.08^{\mathrm{bc}}(0.22)$ & $2.94^{\mathrm{ab}}(0.55)$ & $22.0^{\mathrm{a}}(13.3)$ \\
$\mathrm{C}$ & $3,119.4^{\mathrm{a}}(40.4)$ & $0.35^{\mathrm{b}}(0.19)$ & $0.11^{\mathrm{ad}}(0.01)$ & $0.47^{\mathrm{b}}(0.19)$ & $3.46^{\mathrm{ac}}(0.65)$ & $0.97^{\mathrm{ac}}(0.13)$ & $3.07^{\mathrm{ab}}(0.26)$ & $20.5^{\mathrm{a}}(10.5)$ \\
$\mathrm{D}$ & $4,035.6^{\mathrm{c}}(196.8)$ & $0.57^{\mathrm{bc}}(0.20)$ & $0.20^{\mathrm{ac}}(0.05)$ & $0.77^{\mathrm{bc}}(0.18)$ & $4.44^{\mathrm{ab}}(1.05)$ & $1.21^{\mathrm{ab}}(0.27)$ & $3.00^{\mathrm{ab}}(0.60)$ & $14.2^{\mathrm{a}}(2.1)$ \\
$\mathrm{E}$ & $3,245.5^{\mathrm{ab}}(58.9)$ & $0.64^{\mathrm{bc}}(0.21)$ & $0.10^{\mathrm{ad}}(0.00)$ & $0.74^{\mathrm{bc}}(0.21)$ & $5.04^{\mathrm{b}}(0.27)$ & $1.41^{\mathrm{b}}(0.05)$ & $3.57^{\mathrm{a}}(0.51)$ & $21.6^{\mathrm{a}}(8.1)$ \\
$\mathrm{F}$ & $3,800.1^{\mathrm{c}}(179.6)$ & $0.64^{\mathrm{bc}}(0.05)$ & $0.33^{\mathrm{b}}(0.08)$ & $0.97^{\mathrm{ab}}(0.05)$ & $3.04^{\mathrm{ac}}(0.31)$ & $1.07^{\mathrm{bc}}(0.07)$ & $2.67^{\mathrm{ab}}(0.42)$ & $13.2^{\mathrm{a}}(4.4)$ \\
$\mathrm{G}$ & $3,456.9^{\mathrm{bd}}(85.3)$ & $0.48^{\mathrm{bd}}(0.28)$ & $0.26^{\mathrm{cb}}(0.05)$ & $0.74^{\mathrm{bc}}(0.26)$ & $2.86^{\mathrm{c}}(0.47)$ & $1.08^{\mathrm{bc}}(0.14)$ & $2.20^{\mathrm{b}}(0.24)$ & $11.7^{\mathrm{a}}(1.6)$ \\
$\mathrm{H}$ & $3,034.2^{\mathrm{a}}(85.1)$ & $1.00^{\mathrm{acd}}(0.32)$ & $0.10^{\mathrm{cd}}(0.03)$ & $1.09^{\mathrm{ac}}(0.33)$ & $3.16^{\mathrm{ac}}(0.95)$ & $0.77^{\mathrm{c}}(0.23)$ & $0.71^{\mathrm{c}}(0.19)$ & $6.9^{\mathrm{a}}(2.9)$ \\
\hline
\end{tabular}

Values are means $(n=5)$ and SD between brackets. Mean values in a column followed by the same letter are not significantly different as estimated by the Tukey test $(P<0.05)$ 
Fig. 1 Values of $\mathrm{pH}$ and contents of organic $\mathrm{C}$ and total $\mathrm{N}$ in the mineral substrate of lysimeters for treatments $A, C, E, F, G$ and $H$, according to depth $(n=5)$. The arrows represent the initial values
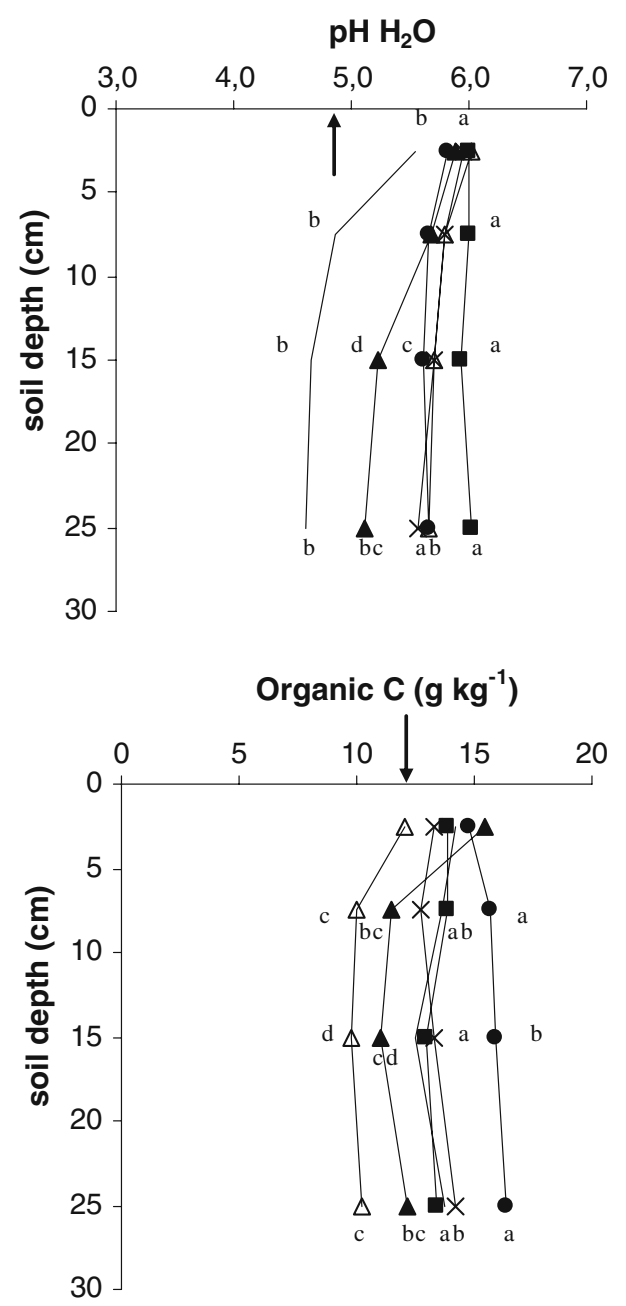

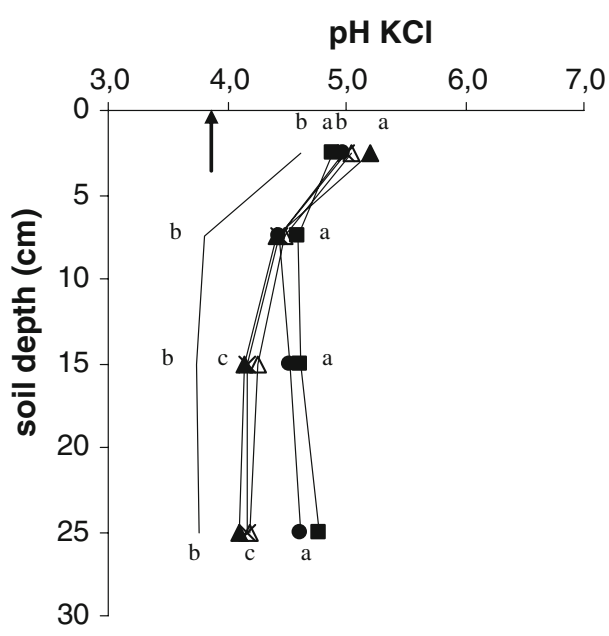

Total $\mathbf{N}\left(\mathbf{g ~ k g}^{-1}\right)$

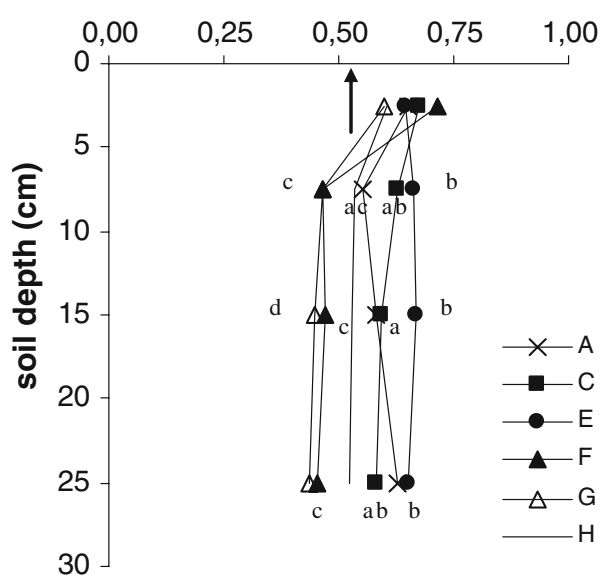

soil surface, after 6 years, were smaller than those at the beginning of experiment (Table 5). These amounts were doubled in treatments with branches in bits (350 and $738 \mathrm{~g}$, respectively, for $\mathrm{B}$ and $\mathrm{F}$ ) relatively to those chopped into chips (159 and $392 \mathrm{~g}$, respectively, for D and G). The amount of organic C in treatment $\mathrm{F}(553 \mathrm{~g})$ was statistically greater than in the others (319-397 g). Amounts of $\mathrm{Ca}$ remaining in residues of $\mathrm{B}, \mathrm{C}, \mathrm{D}, \mathrm{F}$ and $\mathrm{G}$ treatments were $4.1,3.4,2.0,7.7$ and $11.7 \mathrm{~g}$, respectively (data not shown).

Table 5 Remaining residues, amounts of organic $\mathrm{C}\left(\mathrm{g}\right.$ lysimeter $\left.{ }^{-1}\right)$ and organic $\mathrm{C}$ content in the mineral soil $\left(\mathrm{g} \mathrm{kg}^{-1}\right) \mathrm{corresponding}$ to the bulk samples and to the non-humified organic matter fraction at the end of the experimental period

\begin{tabular}{|c|c|c|c|c|c|c|}
\hline \multirow[t]{2}{*}{ Treatments } & \multirow{2}{*}{$\begin{array}{l}\text { Residues } \\
\left(\text { g lysimeter }^{-1}\right)\end{array}$} & \multirow{2}{*}{$\begin{array}{l}\text { Organic } \mathrm{C}^{\mathrm{a}} \\
\left(\mathrm{g}^{\mathrm{g} \text { lysimeter }}{ }^{-1}\right)\end{array}$} & \multicolumn{2}{|c|}{ Organic C (Bulk soil) } & \multicolumn{2}{|c|}{ Non-humified } \\
\hline & & & $0-5 \mathrm{~cm}$ & $5-10 \mathrm{~cm}$ & $0-5 \mathrm{~cm}$ & $5-10 \mathrm{~cm}$ \\
\hline A & - & $337 \pm 18 \mathrm{a}$ & $13.3 \pm 1.0 \mathrm{a}$ & $12.8 \pm 1.0 \mathrm{ac}$ & $3.9 \pm 0.6 \mathrm{a}$ & $3.4 \pm 0.8 \mathrm{a}$ \\
\hline $\mathrm{B}$ & $350 \pm 168 \mathrm{a}$ & $385 \pm 63 a$ & $14.7 \pm 1.3 \mathrm{a}$ & $12.6 \pm 0.6 \mathrm{ac}$ & $6.1 \pm 1.5 \mathrm{a}$ & $4.1 \pm 0.8 \mathrm{ab}$ \\
\hline $\mathrm{C}$ & $323 \pm 104 a$ & $388 \pm 35 \mathrm{a}$ & $15.5 \pm 0.8 \mathrm{a}$ & $11.9 \pm 0.8 \mathrm{ab}$ & $4.5 \pm 1.1 \mathrm{a}$ & $4.3 \pm 0.7 \mathrm{ab}$ \\
\hline $\mathrm{D}$ & $159 \pm 115 \mathrm{a}$ & $319 \pm 19 \mathrm{a}$ & $13.8 \pm 2.3 \mathrm{a}$ & $13.9 \pm 0.5 \mathrm{ac}$ & $6.9 \pm 0.9 \mathrm{a}$ & $3.8 \pm 0.4 \mathrm{ab}$ \\
\hline $\mathrm{E}$ & - & $397 \pm 27 \mathrm{a}$ & $14.8 \pm 1.9 \mathrm{a}$ & $15.8 \pm 1.2 b$ & $5.2 \pm 0.8 \mathrm{a}$ & $5.5 \pm 1.5 b$ \\
\hline $\mathrm{F}$ & $738 \pm 64 b$ & $553 \pm 37 b$ & $15.5 \pm 3.0 \mathrm{a}$ & $11.5 \pm 0.9 \mathrm{ac}$ & $5.6 \pm 3.4 \mathrm{a}$ & $2.5 \pm 0.2 \mathrm{a}$ \\
\hline $\mathrm{G}$ & $392 \pm 129 a$ & $322 \pm 26 a$ & $12.1 \pm 1.1 \mathrm{a}$ & $10.0 \pm 2.4 \mathrm{c}$ & $5.6 \pm 0.6 \mathrm{a}$ & $3.6 \pm 1.4 \mathrm{ab}$ \\
\hline $\mathrm{H}$ & - & $335 \pm 38 \mathrm{a}$ & $14.3 \pm 0.5 \mathrm{a}$ & $13.7 \pm 1.5 \mathrm{ab}$ & $5.3 \pm 0.5 \mathrm{a}$ & $4.3 \pm 0.5 \mathrm{ab}$ \\
\hline
\end{tabular}

Values are means $(n=5) \pm \mathrm{SD}$. Mean values in a column followed by the same letter are not significantly different as estimated by the Tukey test $(P<0.05)$

a Including remaining residues 
At the end of the experiment, the content of total organic $\mathrm{C}$ in the surface soil layer $(0-5 \mathrm{~cm})$ increased by 2-3 $\mathrm{g} \mathrm{kg}^{-1}$, as compared to the initial (except treatment $\mathrm{G}$ ). The main differences observed were in the treatments with organic residues on the soil surface that showed contents of organic $\mathrm{C}$ in the $0-5 \mathrm{~cm}$ top soil layer statistically higher than those of the deepest layers $\mathrm{C}$ (Fig. 1). Organic C content in the deeper soil layer tended to be smaller in the $\mathrm{F}$ and $\mathrm{G}$ treatments than in the others. Most of the organic $\mathrm{C}$ corresponded to the humified organic matter fraction (55$78 \%$, Table 5). Pattern of $\mathrm{N}$ content in soil was similar to that observed for the organic $\mathrm{C}$ (Fig. 1).

Residue treatments affected contents of exchangeable $\mathrm{Ca}$ and $\mathrm{Mg}$, and of extractable $\mathrm{P}$ and $\mathrm{K}$, mostly in the top 0-5 cm soil layer (Fig. 2). In this layer, values of exchangeable $\mathrm{Ca}$ in the control and in the other treatments were greater than the initial values. Treatments with the organic residues on the soil surface showed higher content of exchangeable $\mathrm{Ca}$ than in the others; however, these contents decreased strongly in deeper layers reaching values lower than those obtained in treatments with residues incorporated. A similar trend was observed for both the exchangeable $\mathrm{Mg}$ and the extractable P. Extractable $\mathrm{K}$ also varied among treatments in the $0-5 \mathrm{~cm}$ top soil layer, but values were lower in those with higher contents of $\mathrm{Ca}, \mathrm{Mg}$ and $\mathrm{P}$. In the other soil layers, differences among treatments were smaller than in the top soil layer.

\section{Discussion}

Influence of harvest residues on $\mathrm{N}$ leaching depended on the type of material added. Harvest residues other than woody residues (branches) increased $\mathrm{N}$ leaching by $44 \%$ as compared with the control; the additional $\mathrm{N}$ leaching, however, was only $21 \%$ of the $\mathrm{N}$ introduced in the lysimeters through residues. In contrast, mixing branches with other residues (forest floor litter, leaves, bark and twigs) reduced $\mathrm{N}$ leaching in comparison with the control, suggesting that woody material with a high $\mathrm{C} / \mathrm{N}$ ratio (420) promoted $\mathrm{N}$
Fig. 2 Contents of exchangeable $\mathrm{Ca}$ and $\mathrm{Mg}$, and of extractable $\mathrm{K}$ and $\mathrm{P}$ in the mineral substrate of lysimeters for treatments $A, C, E, F, G$ and $H$, according to depth $(n=5)$. The arrows represent the initial values
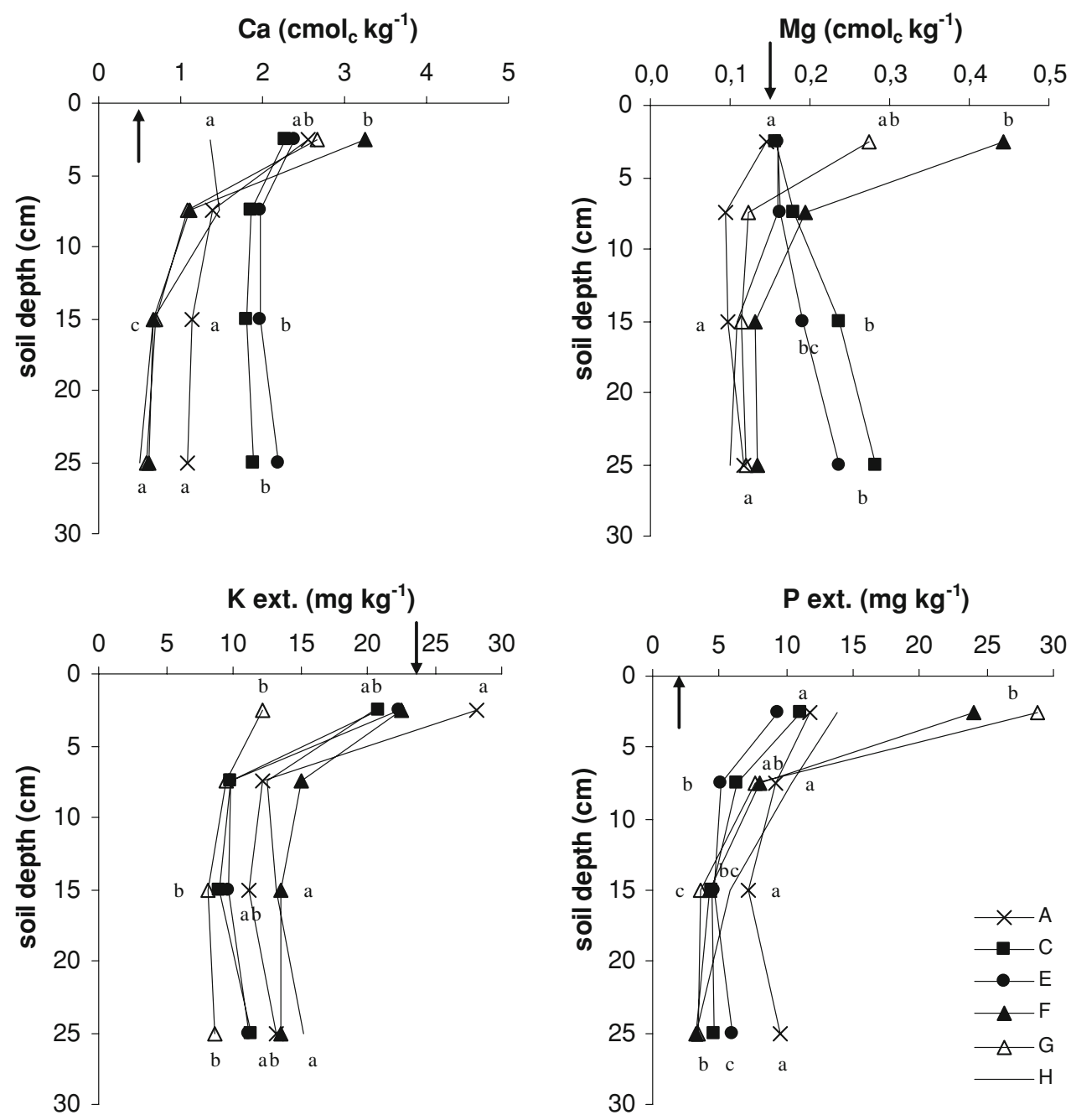
immobilisation. These results are in a good agreement with data reported by Azevedo (2000) and Magalhães (2000) who observed $\mathrm{N}$ immobilisation by decomposing Eucalyptus branches placed on the soil surface or mixed into the soil. The reduction of $\mathrm{N}$ leaching in the present study also relates well with the data reported by Carlyle et al. (1998) in a lysimeter experiment with harvest residues of radiata pine, and those by Pérez-Batallón et al. (2001) in a field experiment with same species.

Woody residue management practices that increase branch specific surface promote $\mathrm{N}$ immobilization into the soil (Carlyle et al. 1998). Our data follow this trend as branches chopped into chips decreased $\mathrm{N}$ leaching by $40 \%$ when placed on the soil surface, as compared with branches cut into bits. Nevertheless, this tendency was not observed when branches, either in bits or in chips, were incorporated into the soil, suggesting that soil conditions regarding humidity and temperature masks the effect of branch fragmentation.

Incorporation into the soil of branches cut in bits had a strong effect in reducing $\mathrm{N}$ leaching as compared to their placement on the soil surface. This agrees with the higher $\mathrm{N}$ immobilisation observed in the former than in the latter (Azevedo 2000; Magalhães 2000). However, branches chopped into chips reduced $\mathrm{N}$ leaching both when incorporated or when placed on the soil surface. This suggests that $\mathrm{N}$ immobilisation by the chips was not related to better contact of chips with mineral soil, indicating that fungi mycellium between residues and soil may play an important role in $\mathrm{N}$ immobilisation, as reported by Holland and Coleman (1987).

As branch bits when placed on the soil surface are not effective in reducing $\mathrm{N}$ leaching, we may accept that branches left on soil surface should be chopped up to increase $\mathrm{N}$ immobilisation. Our results also suggest that incorporation of residues (mostly branches) into the soil is a useful strategy to reduce losses of mineral $\mathrm{N}$ through leaching. Moreover, all residues placed on the soil surface can contribute to retain $\mathrm{N}$, as treatments $\mathrm{F}$ and $\mathrm{G}$ were not significantly different from other treatments.

Despite the great difference relative to the initial amount of organic residues, most of the treatments at the end of the experiment showed $\mathrm{C}$ content and amount of the same magnitude as those measured initially. This agrees well with results from a field experiment (Magalhães 2000; Madeira et al. 2004), where content and amount of organic $C$ in the top soil layer after 7 years were independent of the removal and placement of residues. Our data also agree with those of Mendham et al. (2003), who found that a double amount of harvest residues did not increase the amount of organic $\mathrm{C}$ in the top 0-20 cm soil layer, as compared with the absence of such residues. Furthermore, our results suggest that most of the organic $\mathrm{C}$ from residues was lost from the system, probably as $\mathrm{CO}_{2}$ to the atmosphere, such as reported Johnson and Todd (1998) who found a net loss of organic C from systems where harvest residues were placed on the soil surface or incorporated into the soil.

Woody residues chopped into chips decomposed faster than bits, either placed on the soil surface or incorporated into the soil, which is in agreement with data reported by Carlyle et al. (1998) for woody residues of radiata pine. Following the trend observed in previous studies (Azevedo 2000; Magalhães 2000), incorporation of chips into the soil enhanced their decomposition. This, however, was not observed for the $20 \mathrm{~cm}$ long bits. Placement of residues also affected the concentration of organic $\mathrm{C}$ in the soil. Incorporation of residues, as reported by Carlyle (1993) for sandy soils enhanced the content of $\mathrm{C}$ along soil depth. Conversely, the placement of residues on the soil surface reduced their decomposition, contributing to their retention on the soil surface for a longer period and lack of any increase of soil organic $\mathrm{C}$ content.

Incorporation of residues decreased the volume of leachates when compared with the maintenance of residues on the soil surface. However, it increased $\mathrm{Ca}$ and P leaching, as also reported by Raimundo et al. (2002) in an experiment involving chestnut tree litterfall. This trend may be ascribed to the fact that incorporated residues decompose and release nutrients faster than those decomposing on the soil surface (Azevedo 2000; Magalhães 2000; Ribeiro et al. 2002), independent of the type and fragmentation of residues. Differences for $\mathrm{Ca}$ and $\mathrm{P}$ leaching were more pronounced because they are slowly released from decomposing residues, especially when placed on soil surface as in treatments $\mathrm{F}$ and $\mathrm{G}$. Furthermore, $\mathrm{Ca}$ and $\mathrm{P}$ released from residues on the surface were retained in the top soil due to stronger binding, and thus their losses were reduced by $12-43 \%$ and $36-46 \%$, respectively. This is in agreement with the high contents of extractable $\mathrm{Ca}$ in the top soil found in the $\mathrm{F}$ and $\mathrm{G}$ treatments, whereas $\mathrm{Ca}$ content decreased in the deeper soil layers, being the values similar to those found in the control. Although maintenance of organic residues improved chemical soil properties in all treatments, the gradient of nutrient content with soil depth was dependent on the type of placement.

\section{Conclusions}

Branches left on the site following harvesting reduced $\mathrm{N}$ leaching as compared with other harvest residues. Branches cut into bits are more effective in reducing $\mathrm{N}$ leaching when incorporated into the top soil, while the influence of chopped branches is independent of the method of placement. Maintenance of harvest residues on soil surface or their incorporation should have similar effects on $\mathrm{N}$ 
leaching and on soil organic C content. However, losses of soil water and nutrients were dependent on the residue placement. Residues placed on soil surface positively affected the volume of leachate, but reduced the leaching of base cations and phosphorus. This placement also increased contents of exchangeable $\mathrm{Ca}, \mathrm{Mg}$ and extractable $\mathrm{P}$ in the top soil $(0-5 \mathrm{~cm})$, but decreased the extractable $\mathrm{K}$ content. It did not change soil values in deeper layers. Results suggest that maintenance of harvest residues on the soil surface is the most favourable management method because on one hand it reduces nutrient losses and on the other hand it enhances nutrient contents in the top soil, that is, in the main root zone. Additionally, there is an improvement of water replenishment in deeper soil layers which is important for trees to withstand summer drought.

Acknowledgments Authors want to thank the comments and suggestions of Prof. Edgar de Sousa and Prof. Ana Carla Madeira during the preparation of the manuscript. Laboratory staff of the Departamento de Ciências do Ambiente (Instituto Superior de Agronomia) is acknowledged for their technical assistance and Paulo Marques and Luis Hilario for their help with field work.

\section{References}

Azevedo APA (2000) Estudo da dinâmica do azoto e do carbono em plantações florestais intensivas, Doctoral Thesis. Universidade Técnica de Lisboa, Lisboa

Bruckert S (1979) Analyse des complexes organominéreaux des sols. In: Duchanfour P, Souchier B (eds) Pédologie. 2. Constituants et Propriétés du Sol. Masson and Cie, Paris, pp 185-209

Carlyle JC (1993) Organic C in forested sandy soils: properties, processes and the impact of forest management. N Z J For Sci 23:390-402

Carlyle JC, Bligh MW, Nambiar EKS (1998) Woody residue management to reduce nitrogen and phosphorus leaching from sandy soil after clear-felling Pinus radiata plantations. Can J For Res 28:1222-1232

Haywood JD (1994) Early growth reduction in short rotation loblolly and slash pine in central Louisiana. South J Appl For 18:35-39

Holland EA, Coleman DC (1987) Litter placement effects on microbial and organic matter dynamics in an agroecosystem. Ecology 687:425-433

INMG (1991) Normais climatológicas da região de "Ribatejo e Oeste" correspondentes a 1951-1980. O Clima de Portugal. Fasciculo XLIX, vol 2-2 ${ }^{a}$. Região. Instituto Nacional de Metereologia e Geofísica, Lisboa
Johnson DW, Todd DE (1998) Harvesting effects on long-term changes in nutrient pools of mixed oak forest. Soil Sci Soc Am J 62:1725-1735

Jones HE, Madeira M, Herraez L, Dighton J, Fabião A, Gonzales-Rio F, Fernandez Marcos M, Gomes C, Tomé M, Feith H, Magalhães MC, Howson G (1999) The effect of organic matter management of the productivity of Eucalyptus globulus stands in Spain and Portugal: tree growth and harvest residue decomposition in relation to site and treatment. For Ecol Manage 122:73-86

Madeira M (1989) Changes in soil properties under Eucalyptus plantations in Portugal. In: Pereira JS, Landsberg JJ (eds) Biomass production by fast-growing trees. Kluwer, Dordrecht, pp 81-99

Madeira M (1995) Efeito das plantações de Eucalyptus globulus nas características do solo em condições mediterrânicas (Portugal). Rev Florestal 8(1):3-22

Madeira M, Magalhães MC, Azevedo A, Fabião A, Araújo MC, Pina JP (2004) Efeito da gestão dos resíduos de abate nas características do solo e no crescimento de uma plantação de Eucalyptus globulus em talhadia. Rev Ciên Agrárias 27:414-431 (Abstract in English)

Magalhães MCS (2000) Efeitos de Técnicas de Preparação do Solo e Gestão dos Resíduos Orgânicos em Características Físico-Químicas do Solo de Plantações Florestais, Doctoral Thesis. Universidade Técnica de Lisboa, Lisboa

Mendham DS, O'Connell AM, Grove TS, Rance SJ (2003) Residue management effects on soil carbon and nutrient contents and growth of second rotation eucalypts. For Ecol Manage 181:357372

Pérez-Batallón P, Ouro G, Macías F, Merino A (2001) Initial mineralization of organic matter in a forest plantation soil following different logging residue management techniques. Ann For Sci 58:807-818

Póvoas I, Barral MF (1992) Métodos de análises de solos. Comunicações do IICT. Instituto de Investigação Científica Tropical, série de Ciencias Agrárias, 10, Lisboa

Proe MF, Dutch J (1994) Impact of whole tree harvesting on secondrotation growth of Sitka spruce: the first ten years. For Ecol Manage 66:39-54

Raimundo F, Madeira M, Coutinho J, Martins A (2002) Simulação lisimétrica da gestão de folhada de Castanea sativa. Efeito na lixiviação de nutrientes e nas características químicas do solo. Rev Ciên Agrárias 24:157-172 (Abstract in English)

Ribeiro C, Madeira M, Araújo MC (2002) Decomposition and nutrient release from leaf litter of Eucalyptus globulus grown under different water and nutrient regimes. For Ecol Manage 171:31-41

Smethurst PJ, Nambiar EKS (1990) Distribution of carbon and nutrients and fluxes of mineral nitrogen after clearfelling a Pinus radiata plantation. Can J For Res 20:1490-1497

Vitousek PM, Matson PA (1985) Disturbance, nitrogen availability, and nitrogen losses in an intensively managed loblolly pine plantation. Ecology 66:1360-1376

WRB (2006) World reference base for soil resources 2006, 2nd edn. World Soil Resources Reports No. 103. FAO, Rome 